\title{
Barriers and enablers to undergraduate music students undertaking a Postgraduate Certificate in Education (PGCE) secondary music programme
}

\author{
Thomas Breeze and Gary Beauchamp \\ Cardiff School of Education \& Social Policy, Cardiff Metropolitan University, Cardiff, UK \\ Corresponding author. Email: tbreeze@cardiffmet.ac.uk
}

\begin{abstract}
In the context of falling recruitment to Initial Teacher Education programmes in the UK, this article focuses on motivators and demotivators affecting undergraduate students' attitudes towards training as a teacher and considers these under the broad headings of altruistic (such as wanting to share a love of the subject and working with young people) and pragmatic (stable career, regular salary, good holidays). A review of the literature suggests that there are differences between the US and the UK in terms of the extent to which students can develop an identity as a teacher during their formative undergraduate years. An online survey was distributed to undergraduates in UK higher education institutions, the results were related to the issues identified in the literature and the differences between genders examined. The results suggested that there was no single significant barrier to undergraduate students deciding to train as secondary music teachers, but that there are opportunities to increase the number of students developing an identity as a music teacher while studying for their undergraduate degrees, and some gender-specific issues which could be addressed.
\end{abstract}

Keywords: undergraduate; PGCE; barriers; enablers; secondary

\section{Introduction}

The number of students enrolling on Postgraduate Certificate in Education (PGCE) Secondary (aged 11-18) Music courses in England and Wales has fallen substantially in recent years (e.g. UK Government, 2019). This is part of wider decline, with regular media stories in recent years about unfilled training places (Adams, 2019; Bloom, 2017; Mason, 2016; Richardson, 2017). While some secondary PGCE subjects can see their numbers drop because graduates can enter a related, and perhaps highly paid, industry (e.g. design and technology, mathematics and science), it is less immediately obvious for a drop in music applications. There are factors complicating comparison between the constituent countries of the UK, such as differing GCSE requirements for entrants to secondary teacher training programmes between England and Wales - with England having slightly lower entry requirements (GCSE grade C in English language and mathematics, as opposed to grade B in Wales) - and higher financial incentives for students in England than Wales (Department for Education, 2017; Welsh Government, 2016). There is, however, limited evidence to date of the views of students about what influences their decision to apply for a secondary music PGCE programme. This article outlines an attempt to gather the thoughts and opinions of undergraduate music students at higher education institutions across England and Wales, with the aim of exploring why student applications have dropped for secondary music PGCE courses.

(C) The Author(s), 2021. Published by Cambridge University Press. This is an Open Access article, distributed under the terms of the Creative Commons Attribution licence (http://creativecommons.org/licenses/by/4.0/), which permits unrestricted re-use, distribution, and reproduction in any medium, provided the original work is properly cited. 


\section{Context}

There are many parties interested in exploring motivation to train as a teacher. Internationally, there is a large corpus of work by governments and related agencies, but this can be a pragmatic exercise to assess the impact of their policies and incentives (Low et al., 2011). Kyriacou and Coulthard (2000) and Moran et al. (2001) both reflect a wide range of academic literature which proposes the division of persuading factors into the altruistic, the intrinsic and the extrinsic. Barmby (2006) further proposes a 'children-orientated' factor, which correlates closely with the altruistic and intrinsic factors, and a 'flexibility' factor which relates to the practicalities of the job.

All of these factors can serve as both positive and negative influences. Altruism, in the form of a desire to work with children, is a common positive factor in many international studies (e.g. Fokkens-Bruinsma \& Canrinus, 2014; Manuel \& Hughes, 2006; Taylor, 2006; Watt et al., 2012). Jones and Parkes (2010) conclude that 'altruistic' and 'intrinsic' factors rank highly in importance amongst the undergraduate students but, supporting older work by Jarvis and Woodrow (2005), they also point to the need for a stable career to be an important factor, which may affect music more given the lack of possible stable career paths. Sometimes, however, the positive factors are much more intrinsic and apparently simple, such as a study of Australian students by Manuel and Hughes (2006), where attaining personal fulfilment such as a 'dream' job, are significant. A small-scale Belgian study by Rots, Kelchtermans and Aelterman (2012) suggested that even within groups of students who embark on a teacher training programme, there will still be a mix of altruistic, intrinsic and extrinsic motivations, including those who do not intend to teach - although they note that such attitudes can be changed during the programme. However, Rots et al. (2010) conclude that most students enter teacher education with a motivation to become teachers. Overall, however, studies into the motivation of teachers generally conclude that the altruistic and intrinsic factors outweigh the extrinsic ones (Moran et al., 2001; Thornton, Bricheno \& Reid, 2002).

In contrast, other generic factors can negatively impact on a student's decision to undertake teacher training, whatever the subject. For instance, Braun (2014) highlights external factors, such as a lack of esteem for the teaching profession as a whole, echoed by Hargreaves (2009), as well as the potential impact of class and gender. Additional negative factors include workload (Smithers \& Robinson, 2003) and financial issues (Barmby, 2006).

Government policy in any country can act as both a barrier and an enabler, as incentives and entry requirements are introduced, amended or abolished. In the UK, the policy situation is further complicated with the advent of devolved powers in education to Wales, Northern Ireland and Scotland, with England's increasingly being seen as an 'outlier' (Beauchamp et al., 2015). This does, however, present challenges given its large numerical dominance in terms of teacher training places and the close geographical proximity of many providers, particularly between Wales and England. This means, for instance, that if a student decides to train as a teacher in Wales, they may receive lower financial incentives for shortage subjects and good degree results (DfE, 2017; Welsh Government, 2016) and be subject to higher exceptions at GCSE. Although this can be advantageous for students, it does present challenges to meeting target numbers. Nevertheless, an international study by Watt et al. (2012) concluded that government policy is more likely to affect perceptions of teaching, rather than motivations for teaching.

Finally, the impact of the media cannot be ignored. In the UK, for instance, the media provide many reasons behind the lack of trainees entering the teaching profession including low pay (National Union of Teachers, 2016), government interference (New Statesman, 2016) and issues around the violent behaviour of students (Richardson, 2016). 


\section{Identity: musician or teacher?}

Nevertheless, besides generic perceptions of teaching, there may be other factors which impact (positively or negatively) on student motivation, such as the identity of teachers as scientist, mathematician, or, in this case, musician. A number of articles from the USA attempt to define the selfperceptions which lead undergraduates to identify as either a musician or a teacher before they have completed their undergraduate studies. In England, Garnett (2014) found similar issues, but suggests they could be avoided if pedagogy was an integral part of musicianship from the earliest stages. In this context, Jones and Parkes (2010) define three 'domains' of identity: music educator, performer and general musician and state that a positive sense of identity as a music educator is the only predictor of choosing a career in music teaching, with no correlation with identity as a performer or with any self-perception of performing talent. They conclude the only way to increase the number of students opting for a career in music teaching is to increase their sense of identity as educators via their experience in university, due to the strong influence of the undergraduate years (Isbell, 2008 p.176).

Meanwhile, Pellegrino (2009) points to tension between the two identities of performer and teacher and summarises a discussion between Bernard (2005), Roberts (2007), Bouij (2007), Dolloff (2007) and Stephens (2007) in which the issue of musician identity versus teacher identity is debated at length. In the UK, the idea of the music teacher as a musician in the classroom, and hence a symbiosis of the two supposedly conflicting identities, was proposed significantly earlier by Swanwick (1988) and provides an effective counter-argument which is a more 'altruistic' (Stephens, 2007 p.8) solution to the problem (as well as making for more effective teachers of music) than Bernard (2005) proposes. In response to Bernard's (2005) suggestion that it is necessary for music teachers to find some way of reconciling the two warring identities within them, Stephens prefers to recognise 'the importance of a creative, artistic or musical identity in effective teaching' (2007, p.17).

One of the few more recent UK-based studies into the reasons for choosing to train as a teacher, by Jarvis and Woodrow (2005), does not examine the issue of 'identity' when categorising the findings from its survey of students, possibly because it is not a music-specific study, and perhaps this identity issue is not such a major factor for teachers of some other subjects. The closest definition is 'always wanted to teach'. Furthermore, results for music students (the study surveyed 12 PGCE subjects) were surprising in a number of ways, with music students reporting a very low response to 'vocational' reasons for wishing to teach music, and a zero response for wishing to continue their involvement with their subject. These surprising results, possibly related to the low number of music trainees surveyed, as well as the significant changes in the education landscape in the UK since 2005, make a strong case for a need to investigate these issues again, with a focus on the subject of music.

The aim of this study is to explore factors which impact on undergraduate music students' attitudes towards teaching as a career, and the following research questions were developed:

1. What enabling factors attract undergraduate music students towards a career in secondary music teaching?

2. What demotivating factors, or barriers, do undergraduate music students perceive in choosing a career in secondary music teaching?

3. What is the impact, if any, of gender on differences in barriers and enablers which attract undergraduate music students towards a career in secondary music teaching?

\section{Research design}

In choosing a research instrument to gather data from students in a range of institutions around the UK, three core characteristics of the target population (students who may choose to undertake a music postgraduate teacher training programme) were considered: the large number of potential 
respondents; their geographic distribution; and the ethical and practical difficulty in gaining access to the contact details of individual students. The paper questionnaire is a useful starting point as it allows a large number of respondents to be approached without the researcher being physically present, and the data, if correctly formatted, can be analysed relatively quickly and easily (Cohen, Manion \& Morrison, 2013, p.377). However, a traditional paper-based survey would be both impractical and unwieldy. In this context, an online survey, which is becoming an essential research tool (Vehovar \& Manfreda, 2016), was selected.

Online surveys have many benefits over other survey methods, including the potential of high response rates (Glover \& Bush, 2005), being easier to administer and less work than paper-based surveys (Harlow, 2010). There are also limitations, however, including the potential for selfselection bias (those who reply, e.g., have an interest in teaching music as a career) (Wright, 2005) and the potential non-representative nature of the internet population as a whole (Eysenbach \& Wyatt, 2002). The latter could, however, be avoided by the use of appropriate focused networks, such as university music departments. Overall, the potential advantages of an online survey outweighed any disadvantages, so an online survey was constructed for distribution through appropriate networks.

The questions asked were divided into four categories:

1. Simple multiple-choice questions relating to the identities of the students: age and gender (both optional), type of degree, HE institution, year of study.

2. More complex multiple-choice questions (based on the literature review) gave the opportunity to identify factors currently persuading them, factors currently dissuading them and hypothetical factors which, if present, might increase the likelihood of them choosing to enrol on a PGCE secondary music course.

3. Multiple-choice questions in which students outlined their educational and musical background. This was intended to provide an insight into any possible effect of the recent fracturing of the English school system into many different types of schools, and also to try and glean some information about whether a broad range of types of musicians are currently studying in what have traditionally been 'feeder' courses into PGCE music programmes.

4. A Likert scale attitudinal question (six-point, 0-5 scale) in which students expressed the likelihood of them applying for a PGCE secondary music programme at any point in the future, followed by an opportunity to predict how long between completing their degree and enrolling on the PGCE they would envisage waiting.

The survey was intended to gauge the perceptions of a large number of students of the likelihood of them applying for a PGCE secondary music course at some point after graduating. Linked to this fundamental area of enquiry was an opportunity for students to pick the factors (enablers) that attracted them towards a career in secondary music teaching and, conversely, to identify factors which put them off (barriers). Further questions in the survey were intended to 'paint a picture' of the students' musical backgrounds, as well as their own educational experience, reflecting the diverse range of types of school which now exist in England in particular, to allow for possible correlation between factors.

The questions were drawn from empirical evidence of potential factors affecting reasons for choosing to undertake a music teacher training programme. The process of constructing the survey items aligned with the following research base:

- Categorisations of motivators and demotivators outlined in Jarvis and Woodrow (2005), Barmby (2006) and Jones and Parkes (2010).

- The inclusion of identity issues, as explored by Isbell (2008) and others.

- The inclusion of recent changes in the requirements for entry to Initial Teacher Education courses in Wales in relation to literacy and numeracy (Welsh Government, 2012). 
Table 1. Institutions in sample

\begin{tabular}{|c|c|c|}
\hline Please select your institution & $\%$ & Count \\
\hline Cardiff University & 54 & 25 \\
\hline Leeds University & 13 & 6 \\
\hline Bristol University & 11 & 5 \\
\hline Birmingham Conservatoire & 9 & 4 \\
\hline Liverpool University & 7 & 3 \\
\hline Birmingham University & 2 & 1 \\
\hline Huddersfield University & 2 & 1 \\
\hline Sheffield University & 2 & 1 \\
\hline Total & 100 & 46 \\
\hline
\end{tabular}

After gaining ethical consent under the university ethics protocol, the questionnaire link was emailed to programme directors in $35 \mathrm{HE}$ providers across the $\mathrm{UK}$, who were asked to forward the contents to their UG students. The mailing list was based on information gathered from undergraduate music programmes on UCAS and available contact details on university or conservatoire web sites. No software was required to complete the survey, only an internet connection, and the survey could be completed on both mobile devices (including phones) and fixed PCs. Informed ethical consent was built into the completion of the survey.

\section{Sample}

In total, 46 students completed the compulsory questions in the survey and these students represented eight institutions in England and Wales: seven universities and one conservatoire. One additional conservatoire response was only partially completed and is not included in the results below. Just over half (54\%) of the responses were from students at one university, near to where this study was undertaken as shown in Table 1.

In this purposive random sample, the majority $(76 \%)$ of respondents were female, compared to $44 \%$ of female students who study music at UG level (HESA, 2020). Such responses are not unusual in online survey as respondents self-select whether to participate (Bethlehem, 2010). This does skew the sample in favour of female responses, but there are sufficient male responses to enable a valid comparison to be made. In addition, just over half of responses were received from the nearest university UG music provider. As no attempt was being made to compare providers, all individual responses were considered equally, as, most importantly, all respondents were able to offer 'richly-textured information' (Vasileiou et al., 2018, p.2), relevant to the main aim of the study to explore undergraduate music students' attitudes towards teaching as a career. The great majority of students (over $87 \%$ ) were studying music as a single subject, as opposed to a joint honours degree or some other subject including music.

\section{Results}

\section{Musical background}

When asked for their principal, second and third studies (if applicable), almost every study reported by students was an 'orchestral' or brass band instrument, voice or occasionally the saxophone, as shown in Table 2. 
Table 2. What type of musical ensemble do you participate in on a regular basis? Please select all that apply. Ranked by popularity

\begin{tabular}{|c|c|c|c|}
\hline $\begin{array}{l}\text { What kind of musical ensembles do you participate in on a } \\
\text { regular basis? Tick all that apply }\end{array}$ & $\begin{array}{c}\text { Total } \\
(\%)\end{array}$ & $\begin{array}{l}\text { Female } \\
\text { (\%) }\end{array}$ & $\begin{array}{l}\text { Male } \\
(\%)\end{array}$ \\
\hline Large choir & 50 & 57 & 27 \\
\hline Symphony orchestra & 37 & 37 & 36 \\
\hline Other instrumental ensemble (please specify) & 33 & 34 & 27 \\
\hline Small choir & 33 & 31 & 36 \\
\hline Chamber ensemble & 24 & 23 & 27 \\
\hline Jazz ensemble & 22 & 20 & 27 \\
\hline Chamber orchestra & 17 & 20 & 9 \\
\hline Rock/pop band & 11 & 9 & 18 \\
\hline Big band & 9 & 6 & 18 \\
\hline Brass band & 7 & 3 & 18 \\
\hline Female choir & 7 & 6 & 9 \\
\hline Male voice choir & 7 & 0 & 27 \\
\hline Church or cathedral choir & 4 & 6 & 0 \\
\hline
\end{tabular}

This table shows the dominance of musical experiences that belong to the 'Western classical' tradition, potentially reflecting a body of literature suggesting a mismatch between the 'habitus' of music teachers and the musical interests and identities of the pupils in schools (e.g. Dwyer, 2019; Wright, 2008).

The results will now be considered in two broad categorisations before summarising the data in a conceptual model. These categorisations are intended to represent attitudinal perceptions of enabling, or motivating factors (enablers) or demotivating factors (barriers). The results will hence be structured around the first two research questions, with the third (gender) being interwoven into each section.

\section{What enabling factors attract undergraduate music students towards a career in secondary music teaching?}

To assess current factors which would motivate students, they were asked: 'What factors attract you to the idea of doing a PGCE secondary music course?' Choices reflected the literature discussed above, and in this question respondents were allowed multiple responses so as to gain a full picture. Responses in this and subsequent tables are shown in total, but also shown by gender. The total responses are divided into three categories: significant if responses are above $60 \%$, moderate if $50 \%-59 \%$ and low if $40 \%-49 \%$.

Responses in Table 3 show a mixture of altruistic and pragmatic factors is largely common for both genders. The only factors considered significant are pragmatic issues: a stable career (although more important for female respondents) and a chance to use musical skills. Moderate factors include not only pragmatic issues of good pay but also more altruistic factors of sharing a love of music and a chance to work with young people. There is, however, a significant gender divide on the latter with $57 \%$ of female and only $36 \%$ of male respondents. The only factor classified as low is good holidays.

When asked what additional factors would motivate them to do a PGCE, data in Table 4 again show that pragmatic concerns emerged as significant, with 'a training wage or grant while doing a 
Table 3. What factors attract you to the idea of doing a PGCE secondary music course? Tick all that apply. Ranked by overall popularity and broken down by gender

\begin{tabular}{|c|c|c|c|}
\hline & $\begin{array}{c}\text { Total } \\
(\%)\end{array}$ & $\begin{array}{c}\text { Female } \\
(\%)\end{array}$ & $\begin{array}{c}\text { Male } \\
(\%)\end{array}$ \\
\hline Total count & 46 & 35 & 11 \\
\hline Stable career & 63 & 66 & 55 \\
\hline The chance to use my musical skills in a job & 61 & 60 & 64 \\
\hline The chance to share my love of music with others & 57 & 57 & 55 \\
\hline Good pay once I am a qualified teacher & 52 & 51 & 55 \\
\hline The chance to work with young people & 52 & 57 & 36 \\
\hline Good holidays & 41 & 43 & 36 \\
\hline I had an inspirational teacher and I want to be like them & 30 & 31 & 27 \\
\hline $\begin{array}{l}\text { I already have teaching experience (not a university work placement) } \\
\text { and I know that I enjoy it }\end{array}$ & 28 & 31 & 18 \\
\hline I know something about the job because I have friends/family who are teachers & 20 & 14 & 36 \\
\hline I can't think of anything else to do after graduating & 17 & 17 & 18 \\
\hline I've done a teaching work placement at university and I enjoyed it & 17 & 20 & 9 \\
\hline $\begin{array}{l}\text { Nothing - there is nothing at all that attracts me to the idea of doing } \\
\text { a secondary PGCE }\end{array}$ & 15 & 11 & 27 \\
\hline I know I will get paid while I'm training & 13 & 9 & 27 \\
\hline $\begin{array}{l}\text { I see it as a way into a non-school-based education job - I don't want to be a } \\
\text { classroom teacher }\end{array}$ & 9 & 6 & 18 \\
\hline Teaching is part of my identity & 7 & 0 & 27 \\
\hline I've done a work placement in an industry other than teaching and I didn't enjoy it & 2 & 0 & 9 \\
\hline Something else (please explain) & 0 & 0 & 0 \\
\hline
\end{tabular}

PGCE' clearly the most important motivator (65\%). There is, however, a clear gender divide in this, with $71 \%$ of females, compared to $45 \%$ of males. Money was again the next most important motivator with 'a better starting salary' emerging as a motivator for $52 \%$ of respondents, with no significant gender difference. Although most responses contained no significant gender differences, it is worth considering those that differ. For instance, $54 \%$ of female respondents identified 'Being able to combine teaching with being a professional musician' as a motivator, compared to only $27 \%$ of the males. In addition, and perhaps correlated, $27 \%$ of the male respondents suggested: 'Nothing - I'm definitely not going to do a PGCE secondary music course and I can't be persuaded!', compared to only $9 \%$ of females. Another significant difference was the fact $14 \%$ of the females were motivated by 'More support with numeracy', compared to $0 \%$ of the males.

What demotivating factors, or barriers, do undergraduate music students perceive in choosing a career in secondary music teaching?

It is important to also consider demotivating factors and consider how they may influence decisions to undertake a PGCE, summarised in Table 5. Interestingly, no factor identified in the literature was rated as significant. Nevertheless, some of the key areas presented in press coverage of schools, such as 'poor behaviour' (59\%, with more males than females) and 'workload" (50\%, again more males than females) as the only factors identified by over $50 \%$ of the respondents. Perhaps slightly contradictory to the $54 \%$ of females who identified 'Being able to combine 
Table 4. Which of these would make you more likely to do a PGCE secondary music course? Please tick all that apply

\begin{tabular}{|c|c|c|c|}
\hline & Total $(\%)$ & Female (\%) & Male (\%) \\
\hline Total count & 46 & 35 & 11 \\
\hline A training wage or grant while doing a PGCE & 65 & 71 & 45 \\
\hline A better salary on starting in the profession & 52 & 51 & 55 \\
\hline A more positive profile for the subject of music & 50 & 51 & 45 \\
\hline Being able to combine teaching with being a professional musician & 48 & 54 & 27 \\
\hline $\begin{array}{l}\text { The chance to work with PGCE staff/students as a taster before } \\
\text { applying so that I can be sure I'm doing the right thing }\end{array}$ & 48 & 49 & 45 \\
\hline If schools were nicer places to work & 39 & 34 & 55 \\
\hline $\begin{array}{l}\text { More relevant experience in my undergraduate degree so that } \\
\text { I can be more prepared }\end{array}$ & 28 & 26 & 36 \\
\hline More flexible working arrangements & 26 & 23 & 36 \\
\hline A less negative media portrayal of teaching & 24 & 23 & 27 \\
\hline A reduction in workload for PGCE students & 22 & 20 & 27 \\
\hline $\begin{array}{l}\text { Nothing - I'm definitely not going to do a PGCE secondary } \\
\text { music course and I can't be persuaded! }\end{array}$ & 13 & 9 & 27 \\
\hline More support with numeracy & 11 & 14 & 0 \\
\hline More support with literacy & 7 & 6 & 9 \\
\hline Relaxation of the literacy requirements & 7 & 9 & 0 \\
\hline Relaxation of the numeracy requirements & 7 & 9 & 0 \\
\hline Relaxation of the degree classification requirement & 4 & 3 & 9 \\
\hline $\begin{array}{l}\text { Nothing - I've already decided I'm doing the PGCE secondary } \\
\text { music course and I won't be put off! }\end{array}$ & 2 & 3 & 0 \\
\hline
\end{tabular}

teaching with being a professional musician' as a motivator, $40 \%$ of females considered they would have 'failed as a performer/composer if I become a classroom teacher'. There is also a key gender difference here, with only $18 \%$ of males noting this. Another key gender difference in barriers, although inversely perhaps a positive for the teaching profession as a whole, is that $40 \%$ of females wanted to 'be a classroom teacher, but not a secondary teacher (perhaps primary, further education or higher education)' - compared to only $9 \%$ of males. Another key difference was that $20 \%$ females felt they were 'bad at speaking to a large group' compared to only $9 \%$ of males.

Both genders (33\% overall) identified that 'I want to have a shot at a professional career in performing/composing' - with slightly more males (36\%), compared to females $(31 \%)$ - perhaps indicating a key dilemma for those who have spent many years honing their relevant musical skills.

Of the students who gave 'other' reasons, there was no obvious pattern as shown below:

- I wouldn't want to be limited to just teaching music.

- The unstability (sic) in the profession at the moment.

- Young people not taking music seriously would really upset me.

- Don't want to teach students who don't want to learn.

- it's a career suffering huge government cuts and no support from anyone.

- I'm too old!

- I am worried about the workload of a qualified music teacher and lack of funding/support. 
Table 5. What factors put you off the idea of doing a PGCE secondary music course (even if you think you might do the course)? Please tick all that apply. Ranked by overall popularity and broken down by gender

\begin{tabular}{|c|c|c|c|}
\hline & $\begin{array}{l}\text { Total } \\
(\%)\end{array}$ & $\begin{array}{l}\text { Female } \\
\qquad(\%)\end{array}$ & $\begin{array}{c}\text { Male } \\
(\%)\end{array}$ \\
\hline Total count & 46 & 35 & 11 \\
\hline \multicolumn{4}{|l|}{ No responses above $60 \%$} \\
\hline I am worried about poor behaviour in schools & 59 & 57 & 64 \\
\hline I am worried about the workload of qualified teachers & 50 & 49 & 55 \\
\hline I am put off by a poor representation of teachers in the media & 37 & 31 & 55 \\
\hline I feel I will have failed as a performer/composer if I become a classroom teacher & 35 & 40 & 18 \\
\hline $\begin{array}{l}\text { I want to be a classroom teacher, but not a secondary teacher } \\
\text { (perhaps primary, further education or higher education) }\end{array}$ & 33 & 40 & 9 \\
\hline I want to have a shot at a professional career in performing/composing & 33 & 31 & 36 \\
\hline $\begin{array}{l}\text { I am worried that my musical skills will get worse because I will spend all my time } \\
\text { teaching }\end{array}$ & 30 & 34 & 18 \\
\hline The pay for qualified teachers is not enough & 30 & 26 & 45 \\
\hline I don't want to lose my love of music & 28 & 26 & 36 \\
\hline $\begin{array}{l}\text { I want to be a music teacher, but not in the classroom (for example a peripatetic or } \\
\text { private instrumental/vocal teacher) }\end{array}$ & 28 & 29 & 27 \\
\hline I am worried about the workload during my PGCE & 26 & 20 & 45 \\
\hline I am worried my musical skills are not sufficient to be a teacher & 22 & 20 & 27 \\
\hline I know I won't get any money while I'm training & 20 & 17 & 27 \\
\hline I don't think I'm good at teaching & 17 & 14 & 27 \\
\hline I feel I'm bad at speaking to a large group & 17 & 20 & 9 \\
\hline $\begin{array}{l}\text { I have a different career in mind that doesn't involve teaching or being a professional } \\
\text { performer/composer }\end{array}$ & 15 & 17 & 9 \\
\hline Something else (please explain) & 15 & 17 & 9 \\
\hline Teaching is not part of my identity & 11 & 11 & 9 \\
\hline I am put off by the numeracy requirements & 7 & 9 & 0 \\
\hline $\begin{array}{l}\text { I have done a work placement with university in an industry other than teaching and } \\
\text { I enjoyed it }\end{array}$ & 7 & 6 & 9 \\
\hline I have taught before (not on a work placement) and I know I don't like it & 7 & 6 & 9 \\
\hline I am put off by the literacy requirements & 4 & 6 & 0 \\
\hline I have done a teaching work placement with university and I didn't enjoy it & 2 & 0 & 9 \\
\hline $\begin{array}{l}\text { Nothing - there is nothing at all that puts me off doing a PGCE secondary music } \\
\text { course }\end{array}$ & 2 & 3 & 0 \\
\hline
\end{tabular}

\section{Discussion}

In discussing the findings, we are mindful of the difficulty in understanding the detailed motivations of respondents due to the nature of the survey responses, and the dominance of female respondents. Indeed, we suggest below that a more detailed exploration through in-depth interviews would help to add further nuance to the findings. Despite these notes of caution, however, the data reveal interesting, and potentially useful, areas for discussion. 
Table 6. Summary of enabling factors and barriers to secondary music PGCE for undergraduate musicians

\begin{tabular}{|c|c|c|c|}
\hline $\begin{array}{l}\text { Percentage } \\
\text { response }\end{array}$ & Ena & abling factors $f=$ female $; m=$ male & Barriers \\
\hline \multirow[t]{2}{*}{$\begin{array}{c}\text { Significant } \\
60 \%+\end{array}$} & $\begin{array}{l}\text { Potential } \\
\quad \text { enabler }\end{array}$ & $\begin{array}{l}\text { Female: } \\
\text { - A training wage or grant while doing a } \\
\text { PGCE }(f=71 \% ; m=45 \%)\end{array}$ & \\
\hline & $\begin{array}{l}\text { University } \\
\text { motiva- } \\
\text { tor }\end{array}$ & $\begin{array}{l}\text { Both gender: } \\
\text { - Stable career ( } f=66 \% ; m=55 \%) \\
\text { - The chance to use my musical skills in } \\
\text { a job }(f=57 \% ; m=64 \%)\end{array}$ & \\
\hline \multirow[t]{2}{*}{$\begin{array}{l}\text { Moderate } \\
50 \%- \\
59 \%\end{array}$} & $\begin{array}{l}\text { Potential } \\
\quad \text { enabler }\end{array}$ & $\begin{array}{l}\text { Both gender: } \\
\text { - A better salary on starting in the pro- } \\
\text { fession ( } f=51 \% ; m=55 \%) \\
\text { - A more positive profile for the subject } \\
\text { of music }(f=51 \% ; m=45 \%) \\
\text { Male: } \\
\text { - If schools were nicer places to work } \\
\text { ( } m=55 \% ; f=34 \%)\end{array}$ & \multirow[t]{2}{*}{$\begin{array}{l}\text { Both gender: } \\
\text { - I am worried about poor behaviour in } \\
\text { schools ( } m=64 \% ; f=55 \%) \\
\text { - I am worried about the workload of } \\
\text { qualified teachers }(m=55 \% ; f=45 \%) \\
\text { Male: } \\
\text { - I am put off by a poor representation } \\
\text { of teachers in the media }(m=55 ; f=31)\end{array}$} \\
\hline & $\begin{array}{l}\text { University } \\
\text { motiva- } \\
\text { tor }\end{array}$ & $\begin{array}{l}\text { Both gender: } \\
\text { - The chance to share my love of music } \\
\text { with others ( } f=57 \% ; m=55 \%) \\
\text { - Good pay once I am a qualified teacher } \\
\text { ( } f=51 \% ; m=55 \%) \\
\text { Female: } \\
\text { - Being able to combine teaching with } \\
\text { being a professional musician ( } f=54 \% \text {; } \\
m=27 \%) \\
\text { - The chance to work with young people } \\
(f=57 \% ; m=36 \%)\end{array}$ & \\
\hline \multirow[t]{2}{*}{$\begin{array}{c}\text { Low } 40- \\
49 \%\end{array}$} & $\begin{array}{l}\text { Potential } \\
\text { enabler }\end{array}$ & $\begin{array}{l}\text { Both gender: } \\
\text { - The chance to work with PGCE staff/ } \\
\text { students as a taster before applying so } \\
\text { that I can be sure I'm doing the right } \\
\text { thing ( } f=49 \% ; m=45 \%) \\
\text { - Good holidays }(f=43 \% ; m=36 \%)\end{array}$ & \multirow{2}{*}{$\begin{array}{l}\text { Female: } \\
\text { - I feel I will have failed as a performer/ } \\
\text { composer if I become a classroom } \\
\text { teacher ( } f=40 \% ; m=18 \% \text { ) } \\
\text { - I want to be a classroom teacher, but } \\
\text { not a secondary teacher (perhaps pri- } \\
\text { mary, further education or higher educa- } \\
\text { tion) ( } f=40 \% ; m=9 \%)\end{array}$} \\
\hline & $\begin{array}{l}\text { University } \\
\text { motiva- } \\
\text { tor }\end{array}$ & & \\
\hline
\end{tabular}

We propose that, while altruistic motivations and practical job-related features (pay, holidays, stable career) are strongly attractive to both genders, overall, they are both slightly more attractive to females, than males, in this sample. We also suggest that, in this sample at least, the male respondents appear to have come to a clearer conclusion that teaching is for them or not, as not only were males more likely to report teaching as being part of their identity, they were also more likely to report that nothing attracted them to teaching, or that they had already decided they would make a bad teacher.

Table 6 provides a summary of the perceived potential enabling factors and barriers to secondary music PGCE, and hence secondary music teaching, for undergraduate musicians. Most items are reported as applying to both genders. However, a more nuanced analysis shows that some apply more to a single gender. If there was a gap of more than $20 \%$ between the genders, these items are reported as applying more to one gender only. As in other tables, responses are considered: significant if responses are above $60 \%$, moderate if $50 \%-59 \%$ and low if $40 \%-49 \%$. No responses below $39 \%$ are considered in this table, but can be found in Tables $3-5$. The table also 
importantly splits each level of response into 'potential enabler', those outside the control of universities and 'university motivator', potentially within their control to promote.

\section{Conclusions}

This study suggests that undergraduate music students do not perceive any significant (more than $60 \%$ ) barriers to undertaking a PGCE in secondary music. In addition, while the perennial issues of teacher workload and pupil behaviour are not within the control of university music departments, this study suggests that there are generic areas which can be promoted by universities which may appeal to potential applicants. Furthermore, there are also distinctive issues that could be addressed with male and female students to inform and encourage them to consider a PGCE programme as the next steps in their career.

Having said this, this research is just the first step in probing these issues in more detail in future in-depth qualitative research. This is situated in a downward trend in numbers applying to study a PGCE in Secondary Music, despite this research suggesting that there are more enablers than barriers to encourage undergraduate music students to undertake a PGCE. For instance, the data suggest that there are differences in perceptions based on gender, which would benefit from in-depth analysis.

Overall, we conclude, optimistically, that this study suggests that there are more enablers than barriers to encourage undergraduate music students to undertake a PGCE.

\section{References}

ADAMS, R. (2019). Secondary teacher recruitment in England falls short of targets, Available at https://www.theguardian. com/education/2019/nov/28/government-falls-short-on-secondary-teacher-recruitment-targets Accessed 20.03.20.

BARMBY, P. (2006). Improving teacher recruitment and retention: The importance of workload and pupil behaviour. Educational Research, 48(3), 247-265.

BEAUCHAMP, G., Clarke, L., Hulme, M. \& Murray, J. (2015). 'Teacher education in the united kingdom post devolution: convergences and divergences. Oxford Review of Education, 41(2), 154-170.

BERNARD, R. (2005). Making music, making selves: A call for reframing music teacher education. Action, Criticism \& Theory for Music Education, 4(2).

BETHLEHEM, J. (2010). Selection bias in web surveys. International Statistical Review, 78(2), 161-188.

BLOOM, A. (2017). Teacher-training numbers plummet for shortage subjects. Available at https://www.tes.com/news/schoolnews/breaking-news/teacher-training-numbers-plummet-shortage-subjects (Accessed 20.03.20).

BOUIJ, C. (2007). A comment to Rhoda Bernard: Reframing or oversimplification. Action, Criticism, and Theory for Music Education, 6(2), 2-18.

BRAUN, A. (2014). The politics of teaching as an occupation in the professional borderlands: The interplay of gender, class and professional status in a biographical study of trainee teachers in England. Journal of Education Policy, 30(2), $258-274$.

COHEN, L., Manion, L. \& Morrison, K. (2013). Research Methods in Education. Abingdon: Routledge.

DEPARTMENT FOR EDUCATION. (2017). An overview of funding for teacher training. Available at https://getintoteaching. education.gov.uk/funding-and-salary/overview (Accessed 20.03.20).

DOLLOFF, L. (2007). All the things we are: Balancing our multiple identities in music teaching. Action, Criticism, and Theory for Music Education, 6(2), 1-21.

DWYER, R. (2019). Music Teachers' Values and Beliefs: Stories from Music Classrooms. London: Routledge.

EYSENBACH, G. \& WYATT, J. (2002).Using the internet for surveys and health research. Journal of Medical Internet Research, 4(2). doi: 10.2196/jmir.4.2.e13

FOKKENS-BRUINSMA, M. \& CANRINUS, E. T. (2014). Motivation for becoming a teacher and engagement with the profession: Evidence from different contexts. International Journal of Educational Research, 65, 65-74.

GARNETT, J. (2014). Musician and teacher: Employability and identity. Music Education Research, 16(2), 127-143.

GLOVER, D. \& BUSH, T. (2005). The online or e-survey: A research approach for the ICT age. International Journal of Research and Method in Education, 28(2), 135-146. 
HARGREAVES, L. (2009). The status and prestige of teachers and teaching. In L. Saha \& G. Dworkin (eds.), The Springer International Handbook of Research on Teachers and Teaching (Vol. 21. Part 1, pp. 217-230). New York: Springer.

HARLOW, A. (2010). Online surveys-possibilities, pitfalls and practicalities: the experience of the TELA evaluation. Waikato Journal of Education, 15(2), 95-108.

HESA (2020). Table 9 - HE student enrolments by subject of study 2014/15 to 2018/19. Available at https://www.hesa.ac.uk/ data-and-analysis/students/table-9 Accessed 05.10.20.

ISBELL, D. S. (2008). Musicians and teachers: The socialization and occupational identity of preservice music teachers. Journal of Research in Music Education, 56(2), 162-178.

JARVIS, J. \& WOODROW, D. (2005). Reasons for choosing a teacher training course. Research in Education, 73(1), $29-35$.

JONES, B. \& PARKES, K. (2010). The motivation of undergraduate music students: The impact of identification and talent beliefs on choosing a career in music education. Journal of Music Teacher Education, 19(2), 41-56.

KYRIACOU, C. \& COULTHARD, M. (2000). 'Undergraduates' views of teaching as a career choice. Journal of Education for Teaching, 26, 117-126.

LOW, E. L., LIM, S. K., CH'NG, A. \& GOH, K. C. (2011). 'Preservice teachers' reasons for choosing teaching as a career in Singapore. Asia Pacific Journal of Education, 31(2), 195-210.

MANUEL, J. \& HUGHES, J. (2006). 'It has always been my dream': Exploring pre-service teachers' motivations for choosing to teach. Teacher Development, 10(1), 5-24

MASON, R. (2016). Labour warns of teacher training crisis after targets missed again. Available at https://www.theguardian. com/education/2016/dec/28/labour-warns-of-teacher-training-crisis-after-targets-missed-again (Accessed 20.03.20).

MORAN, A., KILPATRICK, R., ABBOTT, L., DALLAT, J. \& McCLUNE, B. (2001). 'Training to teach: Motivating factors and implications for recruitment. Evaluation and Research in Education, 15, 17-32.

NATIONAL UNION OF TEACHERS. (2016). Teacher shortage crisis. Available at https://www.teachers.org.uk/news-events/ conference-2016/teacher-shortage-crisis (Accessed 20.03.20).

NEW STATESMAN. (2016). Leader: Stop meddling in our schools. Available at http://www.newstatesman.com/politics/ education/2016/05/leader-stop-meddling-our-schools (Accessed 20.03.20).

PELLEGRINO, K. (2009). Connections between performer and teacher identities in music teachers: Setting an agenda for research. Journal of Music Teacher Education, 19(1), 39-55.

RICHARDSON, H. (2016). Four in 10 teachers 'attacked by pupils'. Available at (http://www.bbc.co.uk/news/education35431782 (Accessed 20.03.20).

RICHARDSON, H. (2017). Drop in teacher training recruits revealed. Available at http://www.bbc.co.uk/news/education39355165 (Accessed 20.03.20).

ROBERTS, B. (2007). Making music, making selves, making it right: A counterpoint to Rhoda Bernard. Action, Criticism \& Theory for Music Education, 6(2).

ROTS, I., AELTERMAN, A., DEVOS, G. \& VLERICK, P. (2010). Teacher education and the choice to enter the teaching profession: A prospective study. Teaching and Teacher Education, 26, 1619-1629.

ROTS, R., KELCHTERMANS, G. \& AELTERMAN, A. (2012). Learning (not) to become a teacher: A qualitative analysis of the job entrance issue. Teaching and Teacher Education, 28, 1-10.

SMITHERS, A. \& ROBINSON, P (2003). Factors Affecting Teachers' Decisions to Leave the Profession. Research Report RR430, London: DES. Available at http://dera.ioe.ac.uk/4759/1/RR430.pdf (Accessed: 20.03.20).

STEPHENS, J., (2007). Different weather. Action, Criticism, and Theory for Music Education, 6(2), 1-31.

SWANWICK, K. (1988). Music, Mind and Education. London: Routledge.

TAYLOR, A. (2006). Perceptions of prospective entrants to teacher education. Teaching and Teacher Education, 22, 451-464.

THORNTON, M., BRICHENO, P. \& REID, I. (2002). Students' reasons for wanting to teach in primary school. Research in Education, 67, 33-43.

UK GOVERNMENT. (2019). Initial teacher training: trainee number census 2019 to 2020. Available at https://www.gov.uk/ government/statistics/initial-teacher-training-trainee-number-census-2019-to-2020 (Accessed 20.03.20).

VASILEIOU, K., BARNETT, J., THORPE, S. \& YOUNG, T. (2018). Characterising and justifying sample size sufficiency in interview-based studies: systematic analysis of qualitative health research over a 15-year period. BMC Medical Research Methodology, 18(148), 1-18.

VEHOVAR, V. \& MANFREDA, K. L. (2016). Online surveys. In N. G. Fielding, R. M. Lee \& G. Blank (eds.), The SAGE Handbook of Online Research Methods Second Edition (pp.143-162). Los Angeles, London: Sage Publications Ltd.

WATT, H. M. G., RICHARDSON, P. W., KLUSMANN, U., KUNTER, M., BEYER, B., TRAUTWEIN, U. \& BAUMERT, J. (2012). Motivations for choosing teaching as a career: An international comparison using the FIT-Choice scale. Teaching and Teacher Education, 28, 791-805.

WELSH GOVERNMENT. (2012). Improving Schools. Cardiff: Welsh Government.

WELSH GOVERNMENT. (2016). Teacher Training Incentives in Wales - Academic Year 2016/17. Cardiff: Welsh Government 
WRIGHT, K. B. (2005). Researching Internet-based populations: Advantages and disadvantages of online survey research, online questionnaire authoring software packages, and web survey services. Journal of Computer-Mediated Communication, 10(3), JCMC1034.

WRIGHT, R. (2008). Kicking the habitus: Power, culture and pedagogy in the secondary school music curriculum. Music Education Research, 10(3), 389-402.

Cite this article: Breeze T and Beauchamp G (2022). Barriers and enablers to undergraduate music students undertaking a Postgraduate Certificate in Education (PGCE) secondary music programme. British Journal of Music Education 39, 232-244. https://doi.org/10.1017/S0265051721000188 